\title{
«Reguengos de Monsaraz, terra de seres encantados que se revelam em noites de luar». Recolha e estudo de algumas lendas da tradição oral
}

Lina Santos Mendonça

Universidade de Lisboa

lina.santosmendonca@gmail.com

RESUMO

O concelho de Reguengos de Monsaraz (Alentejo-Portugal) apresenta um vasto e rico património cultural e imaterial. As lendas da tradição oral são um exemplo que integra este património e pouca atenção têm merecido nos estudos sobre a cultura deste concelho alentejano. Assim, o presente artigo pretende dar a conhecer uma recolha de um conjunto de lendas da tradição oral de Reguengos de Monsaraz, bem como os temas e os motivos que as inserem no panorama das lendas tradicionais portuguesas. Igualmente, deseja contribuir para um conhecimento mais alargado das lendas da tradição oral portuguesa, para uma reflexão sobre a presença do elemento sobrenatural no corpus apresentado $e$ sobre a importância do corpus, enquanto património cultural imaterial.

PALAVRAS-CHAVE

Lendas; tradição; oral; Reguengos de Monsaraz; sobrenatural

ABSTRACT

The municipality of Reguengos de Monsaraz (Alentejo-Portugal) has a vast and rich intangible cultural heritage. The legends from the oral tradition are an example of this heritage and have received little attention in studies on the culture of the Alentejo region. This article therefore presents a set of legends from the oral tradition of Reguengos de Monsaraz and examines the themes and motifs that qualify them as traditional Portuguese legends. It also intends to expand current knowledge of the legends of the 


\section{Lina Santos Mendonça}

Portuguese oral tradition, to reflect on the presence of supernatural elements in the corpus presented and to highlight the importance of the corpus as intangible cultural heritage.

\section{KEYWORDS}

Legends; tradition; oral; Reguengos de Monsaraz; supernatural

\section{RESUM}

El municipi de Reguengos de Monsaraz (Alentejo-Portugal) té un vast i ric patrimoni cultural i immaterial. Les llegendes de tradició oral són un exemple que integra aquest patrimoni i que han merescut poca atenció en els estudis sobre la cultura d'aquest municipi d'Alentejo. Per això, aquest article pretén presentar un recull d'un conjunt de llegendes de la tradició oral de Reguengos de Monsaraz, així com els temes i motius que els insereixen en el panorama de les llegendes tradicionals portugueses. Així mateix, es vol contribuir a un coneixement més ampli de les llegendes de la tradició oral portuguesa, a fer una reflexió sobre la presència de l'element sobrenatural al corpus presentat i a remarcar la importància del corpus com a patrimoni cultural immaterial.

\section{PARAULES CLAU}

Llegendes; tradició; oral; Reguengos de Monsaraz; sobrenatural

REBUT: 30/O3/20I9| ACCEPTAT: 29/O8/20I9 


\section{Introdução'}

No início do século xx, o poema «Reguengos», de J. Frederico Brito, publicado no semanário $O$ Guadiana, apresentava, em alguns dos seus versos, a então vila de Reguengos de Monsaraz como «Terra de contos de fadas/ De moiras enfeitiçadas/ Que andam bailando ao luar» (vv. 2-3) (Brito I927: I), revelando a presença de elementos de natureza fantástica associados à sua identidade cultural, introduzida com a expressão «Terra de» (v.I), e a sua vocação para o ato de narrar, relatar, contar («Terra de contos»). O poema prossegue, depois, com a continuação do retrato identitário da localidade alentejana, com o apontamento de traços ligados à paisagem envolvente, aos habitantes e ao cante alentejano, por exemplo, para ser, finalmente, rematado com os versos com que havia começado: «E enquanto Reguengos dorme,/ Anda o vento p'las quebradas,/ Co'as moiras enfeitiçadas/ Que andam bailando ao luar» (Brito I927: I).

Se evocamos aqui os versos de J. Frederico Brito é porque desejamos sublinhar, à sua semelhança, um dos traços identitários da cultura reguenguense, a existência de lendas que têm circulado, por via oral, de geração em geração (as «moiras enfeitiçadas/ Que andam bailando ao luar»). Assim, o nosso principal objetivo é apresentar e dar a conhecer um conjunto de lendas tradicionais que recolhemos junto da comunidade do concelho de Reguengos de Monsaraz (distrito de Évora/ Alentejo - Portugal) e que se enquadram no universo temático das lendas da tradição oral portuguesa, encontrando também paralelo noutros locais, como a Galiza e diversos países europeus, o Brasil e os países hispano-americanos. Apresentamos $\mathrm{o}$ «corpus» da recolha, em anexo.

Para o reconhecimento deste enquadramento, sempre que possível, remeteremos, em nota de rodapé, para a correspondência com o Arquivo Português de Lendas cuja sigla usada é APL. ${ }^{2}$ Esta relação de correspondência é importante para se perceber, de forma similar, a difusão, a conservação e a vitalidade do «corpus» recolhido. Aliás, a consulta do APL permitiu-nos perceber que, neste arquivo, não se encontra o registo de quaisquer lendas recolhidas no concelho de Reguengos de Monsaraz, relacionadas a nível temático com o «corpus» que recolhemos. Também não encontrámos no ADLOT (Arquivo Digital da Literatura Oral Tradicional) ${ }^{3}$ lendas recolhidas no concelho em evidência. Resultado idêntico obtivemos com a consulta do Catálogo dos Contos Tradicionais Portugueses, de Cardigos e Correia, visto que contos e lendas podem partilhar alguns temas e motivos e apesar de haver, nesta obra, a presença de doze contos recolhidos em Reguengos de Monsaraz. Contudo, no APL, verificámos a presença de algumas lendas recolhidas em localidades do distrito de Évora (Estremoz, Glória, Luz, Nossa Senhora do

I Artigo elaborado no âmbito de CLEPUL/Grupo de Tradições Populares Portuguesas Professor Manuel Viegas Guerreiro Faculdade de Letras da Universidade de Lisboa.

2 O Arquivo Português de Lendas é um projeto da responsabilidade do Centro Ataíde Oliveira da Universidade do Algarve, desenvolvido pelos investigadores Isabel Cardigos dos Reis e Paulo Correia. Está disponível em linha em <http://www.lendarium.org/>.

3 O ADLOT é um projeto desenvolvido no Centro de Tradições Populares Portuguesas Professor Manual Viegas Guerreiro, atual Grupo de Investigação de Tradições Populares Portuguesas Professor Manual Viegas Guerreiro, integrado no CLEPUL - Faculdade de Letras, da Universidade de Lisboa. Foi financiado pela Fundação para a Ciência e Tecnologia de Portugal e teve a direção científica do Professor João David Pinto-Correia. Está disponível em linha em <http://www.adlot.fl.ul.pt/ $>$. 
Bispo, Oriola, Portel, S. Bento do Cortiço, Santa Vitória do Ameixial, S. Sebastião da Giesteira, Vila Viçosa), as quais tratam alguns dos temas e motivos-temáticos em destaque (lobisomens, mouras, cobras encantadas, tesouros encantados e tesouros escondidos), no ponto 3 deste trabalho.

A existência de elementos ou entes sobrenaturais no «corpus», a nosso ver, fá-lo receber a classificação de Lendas de Forças e Seres Sobrenaturais, nomenclatura usada pelo ADLOT e da responsabilidade de Cidraes, por mostrar a natureza dos principais intervenientes na ação. A investigadora explicita a sua nomenclatura:

O medo do desconhecido e a necessidade de explicar fenómenos incompreensíveis dominaram desde sempre a imaginação dos homens. Neles enraízam o sentimento religioso e a crença em divindades temidas ou tidas como protectoras, mas também a crença numa grande diversidade de seres e forças sobrenaturais - monstros, gigantes, diabos, fantasmas, sereias, mouras encantadas, etc. (Cidraes 2013: 2).

Esta posição sobre a presença do elemento sobrenatural nas lendas vai ao encontro da perspetiva de Casinha Nova, apresentada no seu estudo sobre as lendas do sobrenatural da região algarvia:

Neste estudo, consideramos lenda todo e qualquer relato de aparição de uma entidade mítica ou religiosa, ou de qualquer efeito considerado sobrenatural (inclusivamente, um desaparecimento inexplicável e, de alguma forma, relacionado com alguma entidade), causado por uma aparição, ou atribuído a uma pessoa ou a um objecto (por exemplo, um milagre), que apresente uma estrutura narrativa completa (Casinha Nova 2OI2: 3I-32).

Durante o trabalho de campo, observámos que as lendas ainda estão presentes na memória dos mais velhos e aguardam um ouvido atento que as valorize e as registe, porque fazem parte da memória coletiva de uma comunidade. Neste sentido, o trabalho de recolha torna-se relevante e necessário em defesa e preservação da memória e de um património cultural imaterial. Para Vasconcelos, este é um trabalho urgente, uma luta contra o tempo (Vasconcelos I994: 338).

Tal como a recolha, a transcrição do material recolhido é importante para garantir a perpetuação, divulgação e estudo das composições orais, em que o registo escrito é a lembrança ou a memória:

O texto escrito é a recordação, o reflexo gráfico de uma existência viva. A fixação por escrito de textos orais, de qualquer forma, não significa necessariamente o seu fim, nem os marginaliza. Pode mesmo verificar-se um equilíbrio saudável: o oral escreve-se, o escrito torna-se uma imagem do oral, sem que se perca completamente a autoridade da voz (Nogueira 2000: 44).

Desta forma, o texto escrito chegará mais facilmente a um público interessado nestas matérias. Feita a transcrição, torna-se mais fácil a seleção e classificação das composições. 


\section{Critérios de recolha, de transcrição, de seleção e de classificação}

Sobre a recolha, julgamos ser importante referir que se realizou, mediante uma entrevista, no meio ambiente dos informantes, quase sempre em suas casas. As entrevistas foram gravadas em formato áudio-vídeo, para que a sua transcrição fosse o mais fidedigna possível. Durante a transcrição do material recolhido, procurámos respeitar as particularidades linguísticas da pronúncia local, vulgarismos e erros de gramática (Serrano I986: 4I), mantendo as marcas da oralidade. Seguimos a recomendação de Viegas Guerreiro: «Escreva os sons com a fidelidade que puder, mesmo que o alfabeto não seja fonético» (Guerreiro I982: I5). Conservámos também os títulos das lendas tal como foram apresentados pelos informantes e o vocabulário local ou regional. Deixámos, ainda, espaços em branco, assinalados com reticências entre parênteses retos, no lugar das passagens ou palavras incompreensíveis e das hesitações ou falhas de memória do informante. Na nossa ótica, é necessário o respeito pelo enunciado oral, sem preconceitos de índole erudita, para que se possa manter autêntico e genuíno.

Feita a transcrição dos textos, numerámos as várias composições recolhidas e identificámos as várias versões da mesma lenda com uma letra minúscula, junto à numeração, porque os textos orais tradicionais não são fixos e, por isso, têm várias realizações, com as suas versões e variantes. Entendemos aqui os conceitos de versão e de variante, segundo a perspetiva de Catalán, a propósito do romance da tradição oral, segundo a qual a versão é «cada uma de las recitaciones de un romance recogidas de la tradición oral» e a variante corresponde ao motivo enquanto cada «uno de los elementos variables de una versión a outra que se dan en una narración romancística» (Catalán I997: I-2). Com efeito, uma vez que a circulação e a transmissão das narrativas se fizeram por via oral, é comum que, além da aproximação, haja algum afastamento entre as várias versões, com alteração e/ ou perda de informação:

Sendo a tradição oral a fonte de registo e preservação deste género de narrações, nada é mais compreensível do que a diluição sucessiva da componente real que as sustenta, dando espaço à imaginação popular, que as vai moldando, quantas vezes, à medida das 'conveniências' de cada povo, de cada geração (Parafita 20IO: I8).

Os informantes foram devidamente identificados com o nome, idade, profissão, grau de escolaridade, naturalidade e residência. Foi feita, ainda, a indicação da data e local de recolha. Estes dados acompanham cada versão. Sobre a importância do registo desta informação, Parafita afirmou que «uma lenda é uma espécie de foral, atribuído pela cosmogonia a uma comunidade, [...] tal como não se pode alterar um foral [...] o mesmo cuidado há que haver com alguns dos textos mais ancestrais da tradição oral que compõem o nosso património imaterial» (Parafita 2OIO: 2I). Deve, assim, haver sempre o cuidado de identificação das fontes das lendas, para autenticar a sua proveniência. ${ }^{4}$

\footnotetext{
4 Diversos investigadores têm chamado a atenção para a importância do registo das informações pessoais dos informantes, por exemplo, Diogo (20I5: 4O-4I), Fonseca dos Santos (I995: I84), Lopez Serrano (I986: 4I-42) e Viegas Guerreiro (I982: I5). Lopez Serrano sublinha a possibilidade de se conhecer melhor a transmissão, a difusão e os meios sociais de fixação da literatura tradicional, através deste registo (Serrano I986: 42).
} 
Alguns destes «textos ancestrais da tradição oral» dão expressão ao património cultural imaterial do concelho de Reguengos de Monsaraz. As lendas da tradição oral recolhidas apresentam uma narrativa breve, estruturada de forma simples, sobre um facto localizado no tempo e no espaço («nalgum tempo» e «nalgum lugar» —o passado é remoto e o espaço é reconhecido). São consideradas pela comunidade como um relato que oferece a possibilidade de apresentar personalidades históricas, entes sobrenaturais, encantamentos, entre outros, e explicar acontecimentos tidos como reais, em lugares muito concretos, cujo universo de representação do mundo tem, com frequência, uma natureza fantástica, incluindo a transformação (por exemplo, o lobisomem). Estas características distinguem a lenda do conto tradicional, assente em ficção, com a presença do elemento maravilhoso, e «sem tempo» e «sem lugar» (com tempo indeterminado e espaço indefinido), iniciado e finalizado, diversas vezes, com uma expressão formulística («Era uma vez» e «Naquele tempo» são algumas expressões usadas, no início do conto). Na sua proposta de classificação dos géneros da Literatura Oral Tradicional, Pinto-Correia classificou a lenda como um género pertencente ao modo narrativo-dramático (com um registo quase sempre em prosa de «acções completas ou pequenos episódios narrativos, sempre completados pelo diálogo»), inserida num subconjunto denominado de «composições explicativo-exemplares» («por elas, a comunidade pretende explicar aspectos não suficientemente esclarecidos pela razão, para o que adoptam 'relatos' que são considerados ou 'reais' ou aceites como 'verosímeis'»); por sua vez, para o investigador, o lugar do conto é no subconjunto das «composições registadoras-elementares», que «registam casos vários de experiência humana [...], dotados de significação elementar» (PintoCorreia I993: 67-68).

«Diziam essas coisas», «E olhe isso pode ser tudo conversas, mas eu acredito», «estas parece que eram verdades, que a minha mãe contava», estas afirmações proferidas pelos informantes trazem até nós a crença nas lendas como narrativas com «fundo de verdade», a crença de que determinado facto aconteceu há muito tempo num determinado lugar. De facto, ao longo do tempo, os vários especialistas têm reconhecido estes traços definitórios das lendas. Para Braga, as lendas populares «têm quase sempre um fundo de realidade modificado pelas impressões subjectivas, e com a acção do tempo, à medida que o facto deixa de ser compreendido ou conhecido, é também alterado no sentido da plausibilidade» (Braga I994: 3I6). Por sua vez, Parafita define a lenda como «um relato transmitido por tradição oral de factos ou acontecimentos encarados como tendo um fundo de verdade, pelo que são objecto de crença pelas comunidades a que respeitam. [...], [aborda] temáticas reais e localizadas no espaço e/ou tempo, podendo embora incorporar elementos inventados e fantasiados» (Parafita 20IO: I8). Finalmente, Cidraes sintetiza a definição de lenda da seguinte forma: «A lenda é uma narrativa breve, em que são narrados acontecimentos extraordinários, apresentados como verdadeiros ou verosímeis e situados no espaço e no tempo» (Cidraes 20I3: I). Posteriormente, a investigadora retoma e dá ênfase a um conjunto de parâmetros tidos como consensuais na apresentação dos traços identificadores da lenda: 
a estrutura curta e fragmentária da narrativa, a ausência de fórmulas de enquadramento da narração, o registo pessimista, a dupla origem popular/oral ou erudita/escrita, a coexistência da transmissão oral, já não no seio da família, mas em grupos reunidos em ocasiões de convívio, com a transmissão escrita, nas suas várias modalidades [...] durante séculos de larga difusão popular (Cidraes 2OI4: 9).

As últimas definições estão de acordo e contêm as palavras-chave na definição da lenda, enquanto género narrativo da literatura oral tradicional: relato/narrativa, factos, verdade, espaço, tempo e fantástico.

Contudo, observamos o seguinte no «corpus»: algumas das versões são bastante fragmentárias, ao ponto de perderem alguns dos elementos do esquema actancial de uma narrativa, como o diálogo, por exemplo. Referimo-nos, sobretudo, às lendas $n^{\circ}$ I, 2, 3, 4, 5, 6 e I2. Em virtude da sua reduzida estrutura textual, guardam relatos (mais próximos do texto noticioso ou informativo) que vemos como vestígios de narrativas antigas mais extensas e dotadas de maior complexidade, chegando até nós através de informantes mais velhos que nelas reconhecem um elemento identitário da sua comunidade. Estas versões, muito breves e sem uma estrutura narrativo-dramática, com um «carácter episódico» (Casinha Nova 2OI2: 35), têm sido denominadas de «episódio lendário» (Casinha Nova 20I2: 32), «encantamentos» (Oliveira I994: 44) e de «rumores» ou «cacos» (Frazão; Morais 2009: 7).

\section{O corpus de lendas da tradição oral de Reguengos de Monsaraz: temas e motivos}

As lendas que recolhemos, no concelho de Reguengos de Monsaraz, abrem espaço para a voz da memória da comunidade reguenguense, a voz de quem transportou, do passado até ao presente, vários temas das lendas portuguesas, sem prejuízo total do fio narrativo da memória. É esta voz, ouvida ao longo de gerações, que se quer agora materializada na escrita, com a recolha e respetiva transcrição, numa espécie de escrita da oralidade.

Atrás observámos que a localidade de Reguengos de Monsaraz aparece no universo poético como «terra de conto de fadas/ De mouras enfeitiçadas», dançando ao luar; ora «fadas» e «mouras» são entes sobrenaturais do imaginário popular, dotados de vida e movimento. Estes revelam-se à noite, ao «luar», momento propício para a sua revelação ao humano, quase sempre, preso a um sentimento tecido de um misto de medo e de atração. Hoje, quase um século passado após a publicação do poema «Reguengos», já (ou ainda) não encontrámos, exatamente, a figura da moura encantada na memória dos reguenguenses. As lendas que recolhemos não nos falam de «mouras encantadas» (com exceção de um título atribuído pela informante à lenda $\mathrm{n}^{\circ} 2$, «A cadeirinha da cobra de moura»), denominação muito comum, falam-nos de um seu correspondente no imaginário popular, a cobra. Em algumas zonas do país, há o uso dos termos «Bichas-mouras» e «Mouras-serpentes». No Alentejo, há a preferência pelo epíteto «Cobra encantada» (Lopes 2003: 5).

A escolha da cobra relaciona-se com vários simbolismos: 
o simbolismo da fertilidade [...] pelo grandioso espectáculo que oferece quando irrompe das covas, no dealbar da Primavera; igualmente, por nele hibernar, relaciona-se com o mundo subterrâneo, o mundo gerador de tesouros preciosos [...]; é também símbolo de regeneração e de cura, porque muda de pele e parece rejuvenescer; assim, a ele também se alia o poder de curar todas as enfermidades, até a da idade e do envelhecimento; por outro lado, move-se à vontade nas águas e os seus movimentos sinuosos fazem lembrar o correr dos rios e dos ribeiros [...]. Mostra-se, assim, ser senhora de todos os ambientes gerados pela Terra-Mãe, terra, água, ar e fogo (Frazão; Morais 2009: 3I-32).

Esta perspetiva simbólica acerca da cobra/serpente podémos encontrá-la defendida por outros investigadores como Quintía Pereira, por exemplo. O investigador salienta o carácter antagónico da simbologia associada a este ser e recorda que, para o cristianismo, a serpente representa o mal e o pecado, por oposição a outras culturas e religiões anteriores, em que a serpente assumia uma conotação positiva e era tida como um símbolo das deusas mediterrânicas e orientais associadas à terra e à fertilidade (Pereira 20I6: 8I).

A cobra encantada aparece como uma figura feminina híbrida (metade mulher-metade cobra) que penteia os seus cabelos, sentada no gargalo de um poço (símbolo de abundância e a fonte da vida, enquanto nascente de água, e símbolo de segredo e de dissimulação da verdade, porque favorece o mistério e a fantasia), como podemos ler nas versões ra e ib, recolhidas em Reguengos de Monsaraz.

Alguns anos afastam as versões Ia e Ib. Na passagem do tempo, entre as duas versões, perdeu-se a informação sobre a identificação do poço («poço do Poceirão») e a cor dos cabelos da cobra, «cabelos pretos»: «aparecia sentada no gargalo do poço a pentear os cabelos pretos». Embora esta cor se afaste do tom «loiro» (os «cabelos de ouro») muito frequente na tradição, não é desusada em lendas alentejanas; por exemplo, aparece numa versão de Vila Alva (Alentejo) (Lopes 2003: 25). Consiglieri Pedroso explica uma superstição associada às cobras de cabelos negros, na qual se subentende que são possuidoras de um génio maléfico: «Em Villa Alva a madrugada de San João é supersticiosamente temida, sendo crença que ninguém a essa hora deve sair para o campo antes do sol nado, para não encontrar cobras encantadas, a pentearem os cabellos negros» (Pedroso I88I: I4).

Segundo Quintía Pereira, a figura mítica da moura encantada é anterior ao cristianismo e possui traços que a relacionam com antigas divindades femininas ligadas à natureza e/ou destino (Pereira 20I6: II). Alguns investigadores não só se referem a vestígios de paganismo associados à moura encantada como a uma possível relação com a pré-história. Para Consiglieri Pedroso, «as mouras encantadas eram divindades ou genios femininos das águas, análogas ás nixen germânicas, ás vilas servias, ás elfen escandinavas, ás náiadas gregas etc.» (Pedroso I88I: 3).

A moura (ou cobra) encantada é uma figura feminina de beleza singular que, geralmente, penteia os seus cabelos louros com pentes de ouro. Casinha Nova explica que, por vezes, as mouras «transformam-se em cobras, que podem ou ser providas de cabelo, conforme sejam totalmente cobras ou apenas metade, com a cabeça humana» (Casinha Nova 20I2: 54). A investigadora acrescenta que, em algumas lendas, as mouras oferecem «figos aos passantes, mas os figos transformam-se em ouro e, mais tarde, fruto da curiosidade e, sobretudo da ambição, em carvão» (Casinha Nova 2OI2: 54). Na tradição galega, a figura da moura apresenta 
um retrato semelhante ao da tradição portuguesa, pois conserva um conjunto de atributos, comportamentos e características comuns (Pereira 20I6: 39-48).

Outra versão, recolhida na aldeia de S. Marcos do Campo, mostra que há vários motivos-temáticos/mitemas que contribuem para construção de um arquétipo de lendas das cobras encantadas, como estar a pentear-se e estar sentada num poço, num banco ou numa pedra, à saída de uma povoação, já afastada da população, em geral. Assim, na versão de S. Marcos do Campo (lenda no 2), a cobra está sentada numa «cadeirinha feita em pedra», à «saída para a» aldeia da Amieira.

Frequentemente, a cobra aparece em locais privilegiados como antigas ruínas, grutas, penedias, covas, pedras, fontes, poços, rios e ribeiros, nas noites de S. João, no solstício de verão, ao meio-dia ou à meia-noite (Vasconcelos I888: 94-95).

No que ao espaço concerne, segundo Casinha Nova, «Os poços, as noras, os valados, os barrancos e os pegos são locais onde, por diferentes razões, se dá (ou deu) a junção dos dois elementos, água e terra, porque sendo covas, buracos, contêm água, pelo que o seu simbolismo é duplo» (Casinha Nova 20I2: 248). Neste sentido, o poço, por um lado, pode estar associado à abundância, à fonte de vida e ao segredo, quando ligado à água; por outro lado, quando ligado à terra, pode relacionar-se com a fecundidade e a regeneração.

Nas versões que recolhemos, no que à circunstância de tempo diz respeito, apenas se diz que a cobra aparece «Num dia do ano» ou «em certos dias», revelando que há uma data singular para o seu aparecimento, sem qualquer especificação, embora seja frequente nas lendas uma localização temporal mais definida, situada na História. Estamos de acordo com Casinha Nova quando diz encontrar situações intermédias: «Se, por um lado, algumas lendas necessitam dessa precisão para provarem certos fenómenos, por outro lado, em particular nos episódios lendários, o momento em que os factos ocorreram acaba por não ser importante, perante o insólito dos próprios acontecimentos» (Casinha Nova 20I2: I77).

Quando a cobra aparece ao humano, o seu desejo principal é encorajá-lo a quebrar o seu encantamento. Para isso, a posição por si assumida, desde o início, é a de sedução, penteando os seus cabelos, para o atrair e, de seguida, ultrapassado o medo e feita a conquista, o humano teria de dar a permissão de um beijo que quebrasse o seu encanto.

Igualmente, na cultura galega, a moura aparece a pentear os seus cabelos, denotando uma atitude sedutora e atraindo quem a vê. O seu comportamento é o de uma mulher cheia de sensualidade e de grande atração sexual (Pereira 20ı6: 72).

$\mathrm{Na}$ lenda $\mathrm{n}^{\circ}$ 3, de Reguengos de Monsaraz, a vontade de quebrar o encanto, mediante um beijo, liga-se à vontade de ultrapassar um destino nefasto, uma «princesa» transformada numa cobra (na tradição portuguesa, há várias lendas em que o encantamento em cobra de uma princesa moura é um castigo infligido pelo seu pai, por se ter apaixonado por um soldado cristão). Cidraes vê, no beijo proposto pela cobra, «uma prova qualificadora que permite a revelação da realidade que se oculta sob as formas aparentes e o acesso ao amor, simbolizado pela bela moura, e ao conhecimento, representado pelos tesouros recebidos» (Cidraes 2OI3: 4).

De facto, no imaginário português, normalmente, a cobra (ou a moura) encantada impõe uma condição (um beijo) ao humano para a oferta do tesouro, 
a qual resultará no seu desencantamento. No APL, há mais de uma centena de versões de lendas deste tipo, em que o beijo porá fim ao encantamento. ${ }^{5}$

No entanto, além de se crer na cobra encantada por outrem, também há a crença que lhe atribui a capacidade de encantar, para afastar o elemento humano do espaço em que se encontra e que, provavelmente, protege - um edifício «antigo» e em mau estado de conservação, onde houve presença dos «mouros», no passado (de acordo com Vasconcelos, segundo a crença popular, os monumentos antigos foram construídos pelos Mouros, que eram muito abastados [I882: 280]), como ilustra a lenda $n^{\circ}$ 4, «Lenda do Convento da Loba»: «Aquilo era tudo muito antigo, tudo cheio de buracos, um prédio, ali, os mouros estiveram ali. E apareceu lá uma cobra que encantou aquela moça». Sobre a localização deste edifício, o informante referiu que se situaria «para os lados da Luz», no concelho de Mourão.

Outra particularidade temática das lendas de cobras encantadas é a sua faceta de guardiãs de tesouros. São guardiãs de tesouros escondidos no interior da terra e isso vinca o ambiente rural e telúrico em que surgem. Na lenda no 5 , podemos observar a cobra como um ser encantado, sobrenatural, que zela, de forma poderosa e invencível, pela segurança e preservação de uma mina de ouro, face à ambição humana de riqueza, não deixando sair com vida quem entrasse no local por si guardado: «Mas quem lá fosse abrir aquilo a cobra matava porque tava lá uma cobra encantada. Quem abria a mina já de lá não saía».

Esta lenda recupera o motivo-temático do «banco de pedra» que, igualmente, se encontra na lenda $\mathrm{n}^{\circ}$, uma «cadeirinha feita em pedra». Com efeito, o «banco» e a «cadeirinha» remetem para peças de mobiliário usadas para o repouso, numa atitude mais passiva e contemplativa ou de exposição/exibição, só alterada pela presença de outro ser. No caso particular destas lendas, não só contribuem para completar o retrato tradicional da cobra sentada como se de um elemento de cenário se tratasse, mas também como um elemento de força que veda o acesso a um espaço de promessa de riqueza, a «mina d'ouro»; assim, a pedra oculta o interior da terra, interdito à presença humana («quem lá fosse abrir aquilo a cobra matava [...]. Quem abria a mina já de lá não saía»). Porém, há quem relacione a pedra à fertilidade: «as pedras teñen unha estreita relación coa fertilidade xa que se cre que determinados penedos teñem a faculdade de favorecel» (Pereira 20ı6: Io8). Por exemplo, junto à aldeia de S. Pedro do Corval, no concelho de Reguengos de Monsaraz, era costume as raparigas solteiras atirarem pedras para a umbela de um menir, a «Rocha dos Namorados» (ainda existente), numa tentativa de adivinhação de quantos anos faltariam para o casamento. ${ }^{6}$

Um outro motivo-temático de referência é a «mina d'ouro», símbolo de riqueza e de ambição popular de esperança de melhoria de condições de vida e, em consequência, de ascensão social.

A crença popular na existência de tesouros misteriosos enterrados no subsolo estende-se a várias localidades do concelho (Campinho, Reguengos de Monsaraz e Perolivas) e arredores (por exemplo, Montoito e Aldeias de Montoito, localida-

5 Por exemplo: Motivo de encanto quebrado com um beijo: APL 2272 ( «A Cisterna da Torre da Dona Chama»); APL 2262 («A Cobra do Sabugueiro»).

6 Quíntia Pereira refere a existência de várias tradições semelhantes, em distintas localidades da Galiza, e destaca ainda a sua presença noutros lugares da Europa. Sintetiza também a relação entre os elementos associados ao mito da moura da seguinte forma: «Moura-pedrafertilidade-moura» (Pereira 20I6: IO8-IO9). 
des do concelho do Redondo). Com efeito, o motivo da mina é, assim, comum a quatro lendas que recolhemos em Reguengos de Monsaraz (lendas no 6, 7, 8 e 9), onde a figura da cobra não é convocada a intervir na narrativa.

Nas lendas $n^{\circ} 6$ e $n^{\circ} 7$, a mina é localizada em espaços identificados e reconhecidos pela comunidade envolvente: em casa da Ti Inácia Neves (lenda no 6) e na Herdade dos Perdigões ( $n^{\circ} 7$ ), situada perto da cidade de Reguengos de Monsaraz. Esta identificação torna-se numa forma de o informante credibilizar o relato, reforçada com a nomeação dos protagonistas, o «sogro do Tonho Zé» e o «avô do Tonho Manéli, marido da enfermeira». Os protagonistas destas lendas procuram a mina, porque ouviram alguém contar que em determinado lugar se encontrava uma mina enterrada no subsolo, dentro de uma panela.

Porém, os protagonistas das lendas no 8 e nº 9 decidem cavar até encontrarem a mina, por alguém lhes ter contado sobre o sonho divinatório acerca da localização de uma mina, com a particularidade de a pessoa que teve o sonho não ter ficado com o tesouro escondido, visto que, por ingenuidade ou por incredulidade quanto ao poder divinatório do sonho, não guardou segredo e partilhou o sonho com outrem. Como diz o provérbio popular, «amigos, amigos, negócios à parte» ou, para recordar uma antiga superstição portuguesa, quando se sonha três noites seguidas com dinheiro enterrado, não se deve revelar o sonho a ninguém para se poder encontrá-lo; se se revelar, não se encontra (Vasconcelos I882: 2II).

Diferentemente do que acontece nas lendas de tesouros de mouros, o sucesso da procura depende exclusivamente de quem o faz, sem sujeição a uma prova representativa de um obstáculo ou das «dificuldades que se colocam ao homem na sua busca do amor e do conhecimento» (Cidraes 2OI4: 57). Nestes relatos de tesouros, o sonho reveste-se de um papel profético e anuncia uma forma de enriquecimento que, com facilidade, entusiasma os protagonistas, pois veem nela uma forma de libertação das más condições de vida. Por vezes, a busca é sem sucesso. É o que acontece nas lendas $\mathrm{n}^{\circ}{ }_{5}, 6$ e 7 . Na lenda $\mathrm{n}^{\circ} 5$, o medo de ser morto pela cobra ganha força e impede o homem de ir burcar a «mina d'ouro». Já na lenda no 6 não há certeza do sucesso ou insucesso relativo à procura («ninguém chigou a saber o que é que eles de lá tiraram»). Quanto à lenda nº 7, conta-se que os protagonistas viram a sua procura fracassada: «Fartaram-se de cavar, mas não encontraram nada». Mas, nas lendas no 8 e 9, há sugestão de uma procura com sucesso, porque, numa e noutra, se diz que os protagonistas ascenderam socialmente. Nesta última lenda, a lenda $n^{\circ}$ 9, particularmente, a informante conta que algumas minas de ouro costumavam ter «encantes». Este reconhecimento pode remeter para o conhecimento de algumas lendas de tesouros que exigiam uma prova qualificadora, isto é, perante a descoberta do local onde estava escondido o tesouro, o protagonista vê-se confrontado com a situação de escolher entre dois potes, um cheio de moedas de ouro e o outro cheio de «peste»/doenças malignas ou de um veneno letal.

Neste ambiente fantástico das lendas, há espaço para outras entidades sobrenaturais tão inspiradoras de medo como de atração ou curiosidade. Deste modo, um outro ser singular, de natureza fantástica, aparece como personagem dotada de conflito e como protagonista de algumas lendas, o lobisomem, uma figura conhecida em Portugal, no Brasil e em vários países europeus. Para Vasconcelos, a origem etimológica do termo lobisomem deriva do latim «lupus-homo» e encontra noutras línguas denominações onde a ideia de lobo e homem está presente: 
«Em fr. o lobisomem chama-se loup-garou, em sueco varulf, alemão, Währoolf, em inglez were-wolf, etc» (Vasconcelos I882: 260).

Na lenda no Io, o protagonista é um «humano» que tem de cumprir o seu destino («fatum») encantado, o seu «fadário», segundo as palavras da informante, mediante uma metamorfose em animal —um «fadário» ou um encantamento tão forte que apenas se alterará por meio de uma ação altruísta e corajosa de quem deseje a este ser a recuperação definitiva da forma humana. A informante explicou a existência do lobisomem com base numa superstição antiga, segundo a qual o mais novo de sete irmãos seria lobisomem ou santo.

Neste relato reguenguense, a transformação do estado natural em animal (um burro ou um cão) acontece à meia-noite, numa encruzilhada, rebolando-se no chão. Após a metamorfose, o lobisomem vai «correr o seu fadário» («E em chegando à meia-noite, não sei se têm dias marcados se não, isso não sei, e só fazem isto à meia-noite, numa encruzilhada duma estrada. Rabolam-se, não sei se dizem alguma coisa, se não, e depois ficam feitos num burro ou num cão, num animal, e abalam a correr aquele fadário»). Depois, findado o tempo necessário, regressa à encruzilhada, espaço predisposto para encontros com o sobrenatural (Meireles I999: I3I), onde tinham ficado as suas roupas, e, novamente, deita-se e rebola no chão, até recuperar a forma natural (inicial). Para se quebrar este «fado», será necessário ir buscar a roupa despida, a seguir à transformação, e queimá-la. O fogo torna-se, deste modo, numa forma de purificação. Na tradição, há narrativas em que se fere o lobisomem para se pôr fim ao seu fado. Mas é aconselhada cautela a quem tiver a coragem de anular o efeito do fadário, para que não receba o destino em causa; para tal, não se deve deixar salpicar com o sangue da ferida ou deve voltar a roupa do avesso (Matos 2003: I2-I3).

A forma como a lenda no Io trata a crença popular no lobisomem está de acordo com vários relatos apresentados, em Tradições Populares de Portugal, por José leite de Vasconcelos. Por exemplo, alguns justificam a existência do lobisomem por ser o mais novo de sete filhos (acreditava-se que o destino -a má-sorte- do recém-nascido era evitado, se lhe fosse posto o nome de Bento), outros por ser fruto da relação amorosa entre um compadre e uma comadre, por ser vítima de um feitiço de uma bruxa ou, ainda, em virtude de uma promessa não cumprida. $\mathrm{O}$ «fado» é cumprido, de forma geral, à meia-noite, numa encruzilhada, «espojando-se» nu no chão, depois de ter pendurado a roupa numa árvore, e metamorfoseando-se num animal (burro, cavalo, cão, entre outros). A seguir, começa a correr de forma desenfreada e desalinhada, durante o tempo que estiver estipulado para o efeito. É por ter de «correr o fado» que, no Minho, o lobisomem era chamado de «Corredor». O destino encantado do lobisomem será quebrado se a sua roupa for queimada ou se se conseguir feri-lo, durante o fado. Acreditava-se que era possível identificar um lobisomem em estado natural, pela sua aparência magra, cor amarela e espírito triste. Distinguia-se também o lobisomem pelas orelhas compridas, nariz arrebitado e «cabelos da cova do ladrão de uma cor parda com laivos escuros» (Vasconcelos I882: 262-270).

Na lenda no II (intitulada de «Medo do Roncão d'El Rei»), ouvida desde criança pelo informante, a ação localiza-se na Herdade Roncão d'El Rei, propriedade agrícola da Casa de Bragança, situada perto da aldeia de São Marcos do Campo. A intriga apresenta um vaqueiro que ouve uma voz que ameaça libertar as vacas, se não lhe derem «favas fritas». Aquele, incrédulo, resolve ignorar a exigência fei- 
ta pela voz e, em consequência, a ameaça/sanção é concretizada. De seguida, o vaqueiro ouve novamente a voz, que repete a exigência e a ameaça, e decide satisfazer a imposição daquela, confecionando as «favas fritas». Por fim, como por magia, as vacas aparecem presas na cabana.

Pelo atrás exposto, notamos que, em momento algum, existe uma aproximação temática à lenda no Io, nem há sequer uma menção ao lobisomem. Em jeito de explicação, durante a entrevista, o informante refere que a «voz» escutada pertence a um «lobisomem», sem acrescentar qualquer traço definitório, dentro do retrato desta figura do imaginário popular apresentado anteriormente: «As pessoas diziam que não era uma voz. Chamavam-lhe 'labisomem', fazia figura de pessoa, mas não era, vá, uma pessoa normal. Mais tarde, até havia alguém que dizia que via o vulto, vá, a figura, via a figura mas não sabia distinguir o que era e só que essa pessoa, vá, se podemos chamar pessoa».

Nestas lendas, ainda que exigente e autoritário na lenda no Io, o lobisomem assume um papel pouco violento que não procura ferir a integridade humana. Para Casinha Nova, apesar do aspeto medonho e assustador do lobisomem, no Algarve, este não parece ser feroz nem capaz de cometer atos atrozes e justifica:

A associação entre a figura do lobisomem e a ferocidade interior reprimida é evidente: o aspecto, peludo e feio (como pode ser feio o nosso lado escuro, dominado pelo inconsciente), os actos condenáveis, a transformação do homem em lobo -o animal selvagem e feroz mais próximo do homem, na Europa, e mais parecido ao cão, inofensivo, domesticado, dócil (Casinha Nova 20I2: 67).

Com efeito, na lenda no Io, a figura do lobisomem apenas despoleta medo ou susto, quando atira coices à porta de alguém («e abalam a correr aquele fadário, que o destino deles manda e, se chegam à porta duma pessoa, a pessoa tem medo, fecha a porta e eles às vezes atiram couces e assim»).

Por último, referir-nos-emos à lenda no I2, versões a e b, com uma ação localizada num espaço facilmente identificado pelos habitantes do concelho de Reguengos de Monsaraz, junto ao rio Degebe (a versão a, intitulada pela informante de «Lenda da Rocha do Vigio», é ainda mais específica nesta localização, com a referência à «Defesa do Esporão", propriedade que se situava nas margens do Rio Degebe e que ficou submersa, após a conclusão da Barragem do Alqueva) cujo desenvolvimento temático gira em torno da queda de uma «senhora»/«moça», a partir de uma altura considerável, a qual sobreviveu a uma morte tida quase como certa.

Para a informante da primeira versão, a sobrevivência da «senhora» deve-se, acima de tudo, a uma espécie de milagre, a uma proteção tão singular, própria apenas do domínio sobrenatural, daí a sua afirmação: «Aquilo há uma lenda ali, qualquer mistério na rocha». Deste modo, o que não tem explicação, para a informante, é classificado como lenda. Na versão b, a narrativa mostra uma protagonista curiosa, com vontade de ver a «Rocha do Demo»; porém, avista uma cobra no local e, de seguida, cai num silvado. Para a população local, o fundo de verdade é atestado por dois elementos: a identificação precisa do local da ação e o casamento da «senhora» com um habitante da aldeia mais próxima da Herdade do Esporão, Perolivas («Não morreu, até casou aqui com um moço das Perolivas»). 


\section{Conclusão}

Portanto, recolhemos e apresentámos um «corpus» de doze lendas (com algumas versões muito fragmentárias, os «episódios lendários»), unidas por um elemento comum, o sobrenatural ou, como disse uma informante, histórias que têm «encantes». Em várias lendas, há a indicação de locais muito concretos do concelho de Reguengos de Monsaraz (Perolivas, Defesa do Esporão, Monsaraz, S. Marcos do Campo, Campinho e Herdade dos Perdigões) e de concelhos vizinhos (Montoito, Aldeias de Montoito, Luz). Também encontramos a nomeação de alguns intervenientes/personagens. Tal vem reafirmar o traço de fundo de verdade próprio da lenda.

Embora o «corpus» não seja amplo, é revelador de lendas com significado regional e/ou local, como a «Lenda da Rocha do Vigio» (lenda $\mathrm{n}^{\circ}$ I2a e $\mathrm{n}^{\circ} \mathrm{I} 2 \mathrm{~b}$ ) e a Lenda do «Medo do Roncão d'El Rei» (lenda nº II). Outras lendas, como as da cobra encantada e as do lobisomem (nomeadamente, a lenda no Io), têm uma abrangência nacional. Esta dualidade vai ao encontro da definição da lenda apresentada por Pinto-Correia, na qual dá destaque à referência a lugares concretos, ao alcance nacional e ao significado regional, além da menção de características como a presença de vultos históricos e da temática etiológica (Pinto-Correia I993:67).

As lendas de Forças e Seres Sobrenaturais aqui tratadas versam, por exemplo, sobre o elemento temático da cobra encantada, também denominada de «moura-serpente», que está sentada no «gargalo do poço» ou numa "pedra» e que se penteia. Não recolhemos versões em que a cobra encantada canta melodiosamente ou em que se ouve, durante a noite, o seu tear a trabalhar, por exemplo. Isto pode justificar-se com uma frequência mais reduzida deste tipo de lendas no Alentejo, comparativamente às regiões do Algarve e Norte de Portugal (Lopes 2003: 6). Por outro lado, a nossa investigação (recolha e estudo) ainda se encontra a decorrer (quisemos, pois, neste trabalho, pela primeira vez, dar a conhecer alguns dos resultados já obtidos) e, em virtude disso, futuramente, esperamos ter um «corpus» mais alargado das lendas de Reguengos de Monsaraz.

Além disso, outras versões chegaram até nós com narrativas sobre tesouros escondidos (as «minas») em panelas, no subsolo, onde se desenvolve a sua procura quase obsessiva com sucessivas escavações por parte dos seus «caçadores», e sobre o lobisomem, figura humana em estado natural, sofredora de um «fado» -a metamorfose em animal, que o obriga a «correr o fadário».

Através do cotejo com o APL, vimos que o «corpus» recolhido no concelho de Reguengos de Monsaraz (doze lendas de Forças e Seres Sobrenaturais), se inscreve na tradição oral das lendas portuguesas, pela correspondência de temas e motivos (correspondência essa que também se pode encontrar com as lendas galegas [Pereira 20I6]), com afinidades favoráveis à conservação de um legado comum.

Assim, podemos considerar o «corpus» não só como elemento integrante de uma tradição regional —enquanto objeto de crença pela comunidade reguenguense - e nacional, mas também de um património comum, cultural e imaterial, que ainda goza de vitalidade e que merece não ser esquecido; é, por isso, merecedor de estudo e de divulgação. 
«Reguengos de Monsaraz, terra de seres encantados que se revelam em noites de luar»

\section{Referências bibliográficas}

Braga, Teófilo (I994): O Povo Português nos Seus Costumes, Crenças e Tradições. Vol. 2. Lisboa: Publicações Dom Quixote.

BRITO, J. Frederico (I927): «Reguengos». O Guadiana. Semanário Republicano núm. 2 (I6 outubro): I.

Casinha Nova, Maria Manuela Neves (20I2): As Lendas do Sobrenatural da Região do Algarve. Tese de Doutoramento em Estudos de Literatura e Cultura (Literatura Oral Tradicional). Vol. I. Lisboa: Faculdade de Letras - Universidade de Lisboa.

Cidraes, Maria de Lourdes (2013): Encantamentos, milagres e outros prodígios. Os animais das nossas lendas. <http://www.adlot.fl.ul.pt/> [data da consulta: 27/O2/2OI9].

- (2014): As lendas portuguesas. Temas. Motivos. Categorias. Lisboa: Apenas Livros.

CARdigos, Isabel David; Paulo Correia (20I5): Catálogo dos Contos Tradicionais Portugueses (Com as Versões Análogas dos Países Lusófonos). 2 Vols. Santa Maria da Feira: CEAO - Edições Afrontamento.

Catalán, Diego (I997): Arte Poética del romancero oral. Parte I a . Los textos abiertos de creación colectiva. Madrid: Siglo XXI España Editores.

Diogo, Cláudia (20I5): Lendas e Outras Memórias de Monchique. História, Tradição e Oralidade no Algarve. Faro: Direção Regional da Cultura do Algarve.

FraZÃo, Fernanda; Gabriela MoraIs (2009): Portugal, Mundo dos Mortos e das Mouras Encantadas. Vol. I. Lisboa: Apenas Livros.

Guerreiro, Manuel Viegas (I982): Guia de Recolha de Literatura Popular. Lisboa: Instituto Português do Património Cultural.

Lopes, Aurélio (2003): B.I das Mouras Encantadas. Lisboa: Apenas Livros.

MATos, Alexandre (2003): B.I do Lobisomem. Lisboa: Apenas Livros.

MeIRELES, Maria Teresa (I999): Elementos e Entres Sobrenaturais nos Contos e Lendas. Lisboa: Vega.

NogueIRA, Carlos (200o): Literatura Oral em Verso. A Poesia em Baião. Águeda: Estratégias Criativas.

OliveIRA, Francisco Xavier D'ATAÍde (I994): As Mouras Encantadas e os Encantamentos do Algarve. Loulé: Notícias de Loulé.

PARAfitA, Alexandre (20Io): Património Imaterial do Douro. Narrações Orais. Contos. Lendas. Mitos. Vol. I. Lisboa: Âncora Editora.

Pedroso, Z. Consiglieri (I88I): As Mouras Encantadas. Porto: Imprensa Commercial.

PereIrA, Rafael Quintía (20I6): Análise Estrutural e Simbólica do Mito da Moura. s.l.: Fundación Vicente Risco e Sotelo Blanco, Concellos Allariz e Castro Caldelas, CETRAD e UTAD.

PINTO-CORREIA, João David (I993): «Os géneros da literatura oral tradicional: contributo para a sua classificação». RILP - Revista Internacional de Língua Portuguesa núm. 9 (Julho): 63-69. 
SERRANO, Ricardo Lopez (I986): la recogida de literatura tradicional como actividad educativa. Salamanca: Instituto de Ciencias de la Educacion - Ediciones Universidad de Salamanca.

SANTOS, Idelet Muzart Fonseca dos (I995): «A Busca da Poesia Tradicional na Voz e na Memória: A Pesquisa do Romanceiro na Paraíba». ELO - Estudos de Literatura Oral núm. I: I65-I85.

VAsconcelos, José Leite de (I882): Tradições Populares de Portugal. Porto: Livraria Portuense de Clavel\&C. ${ }^{\text {a }}$.

- (I994): Etnografia Portuguesa. Vol. I. Lisboa: IN-CM.

\section{Anexos}

$\mathrm{Ia}^{7}$

No poço do Poceirão (fica à saída do Campinho quando se vai para a aldeia de S. Marcos), havia pessoas que diziam que viam uma cobra encantada. Da cintura para baixo, era cobra. Da cintura para cima, era mulher. Num dia do ano, aparecia sentada no gargalo do poço a pentear os cabelos pretos.

Serafim C. S. A., 7I anos, reformado, $4^{\circ}$ ano de escolaridade, natural de Campinho, residente em Reguengos de Monsaraz | Reguengos de Monsaraz | 24 de novembro de $201 \mathrm{I}$ |

$\mathrm{Ib}$

O que eu me recordo desde gaiato de ouvir falar ali... Na aldeia do Campinho, há um poço ao lado mesmo encostado às paredes, em que havia aquela lenda que as pessoas contavam, os antigos, que havia alguém que tinha visto uma cobra com cabelo em cima do gargalo do poço. Quer dizer, era uma cobra, mas cabeça de pessoa. Então, diziam que era uma cobra encantada que ali estava. Era a história, aquela velha história que havia certos dias que a cobra que aparecia ali a pentear-se. Se é verdade, se é mentira, ninguém sabe.

Serafim C. S. A., 78 anos, reformado, $4^{\circ}$ ano de escolaridade, natural de Campinho, residente em Reguengos de Monsaraz | Reguengos de Monsaraz | 3 de março de 20I9 |

$2^{8}$

«A cadeirinha da cobra de moura»

À saída para a Amieira, está lá uma cadeirinha feita em pedra, e a gente dizia que se sentava além uma cobra. A gente?! Toda vida as nossas mães. Ia pr'além uma cobra pentear-se.

Maria Clara B., 69 anos, analfabeta, reformada, analfabeta, natural de S. Marcos do Campo, residente em S. Marcos do Campo | S. Marcos do Campo | 24 de novembro de $201 \mathrm{II}$

7 Motivo da cobra sentada no poço: APL 254 («Lenda do Poço da Moura»).

8 Motivo da moura sentada na pedra: APL 3243 («Lenda da Pedra da Moura»). 
Havia outra da cobra, que quem tivesse a coragem de ir àquele sítio, às tantas horas, não sei quando, tinham que deixá-la dar um beijo na face para a desencantar, para que a princesa deixasse de estar encantada.

Serafim C. S. A., 7I anos, reformado, $4^{\circ}$ ano de escolaridade, natural de Campinho, residente em Reguengos de Monsaraz | Reguengos de Monsaraz | 24 de novembro de $201 \mathrm{O}$ |

4

«Lenda do Convento da Loba»

Aquilo era muito antigo, tudo cheio de buracos, um prédio, ali, os mouros estiveram ali. E apareceu lá uma cobra que encantou aquela moça. E a moça desmaiou. Mas a cobra não lhe fez mal, abalou. Mas ela gritou, depois já de passar. Gritou e correu mais família que havia ali. Espreitaram e viram a cobra ainda. E depois desapareceu.

Diziam os antigos que, quando o Degebe enchia, que elas que metiam na cheia, iam pr'aquelas ilhas da Guadiana, onde ninguém arrimava e está a prova que nunca mais ninguém a via.

António R., 95 anos, reformado, analfabeto, natural de São Marcos do Campo, residente em São Marcos do Campo | São Marcos do Campo | 7 de dezembro de 20II |

$5^{9}$

O informante conta que no banco de pedra estava uma cobra encantada.

Diziam que tava lá uma mina, que tava uma mina d'ouro. Mas quem lá fosse abrir aquilo a cobra matava, porque tava lá uma cobra encantada. Quem abria a mina já de lá não saía. E, então, ninguém se arriscou a ir lá abrir a mina. É assim. Falava-se nisto quando era pequeno.

António C. P., 87 anos, reformado, $3^{\circ}$ classe, natural de S. Marcos do Campo, residente em S. Marcos do Campo |S. Marcos do Campo | 24 de novembro de 2OII |

6

Na Peroliva, diziam também que tava aí uma mina nas casas da Ti Inácia Neves. Cavavam, cavavam, cavavam de noite, mas ninguém chigou a saber o que é que eles de lá tiraram. Mas diziam que tava. Os donos da casa é que cavavam e as famílias.

Rosete F. R., 68 anos, reformada, $4^{\circ}$ ano de escolaridade, natural de Gafanhoeiras, residente em Reguengos de Monsaraz | Reguengos de Monsaraz | 24 de novembro de $201 \mathrm{O}$ |

9 Motivo de cobra guardiã de tesouro + sonho com tesouro + medo da população: APL 2I66 («A Cobra e o Tesouro»); APL iI64 («A cobra e o tesouro»).

Motivo do medo da «bicha-moura» / «cobra» guardiã de tesouro: APL 6I7 («Bicha-moura de S. Bartolomeu»); APL IO24 («A cobra moura»). 
7

O sogro do Tonho Zé e o avô ali do marido da enfermeira eram cunhados. Então, eles ouviam a história que... Esse parece mesmo que era os Perdigões e a pessoa que tinha contado que existia uma mina ali nos Perdigões. E eles os dois, os dois cunhados ouviram aquilo, combinaram os dois:

- É, a gente vamos lá.

- Então, vamos lá.

Uma bela noite foram e, então, começaram a cavar e fartaram-se de cavar, não viam nada.

Dizia o avô ali do Tonho Manéli pró cunhado:

- Cava, compadri, cava qu'ê já vejo ali uma luzinha. Cava qu'ê já vejo ali uma luzinha. Cava.

Fartaram-se de cavar, mas não encontraram nada.

Ao fim de tempo, é que eles descobriram que tinham apanhado uma barrigada de cavar à procura da mina.

Serafim C. S. A., 78 anos, reformado, $4^{\circ}$ ano de escolaridade, natural de Campinho, residente em Reguengos de Monsaraz | Reguengos de Monsaraz | 3 de março de 20ı9 |

$8^{\text {10 }}$

Também reza a história, ali em Monsaraz, segundo se conta que alguém sonhava com uma mina e estava cheia de moedas de ouro. Mas a pessoa foi sonhando, sonhou várias vezes com aquilo e não estava a ligar, até um dia descobriu a um amigo. Aquilo foi passando, foi passando. E esse amigo, quando foi prá tropa, encontrou-se lá com um rapaz do Campinho — estava lá a servir na tropa e contou-lhe:

- Olha lá, tenho ouvido esta história, que há uma mina assim, assim, ali ao pé de Monsaraz. Mas eu só vendo é que acredito. Queres ir comigo?

- Pode ser. Se apanharmos um engano, é um engano. Também ninguém precisa de saber se é engano.

E eles lá foram os dois, uma noite.

Se encontraram alguma coisa, ninguém sabe.

Só que, mais tarde, aquele que sonhava foi lá ter ao local e encontrou lá vestígios de tar ali uma panela de barro, estava lá ainda a panela. Só que não tinha nada. Reza a história que alguém tinha tirado alguma coisa do que lá estava.

Mas foi verdade ou foi mentira, o que é certo é que as pessoas que dizem que foram lá aumentaram na vida, e só com o trabalho não dava. Seria verdade se havia lá ouro, só eles é que podem saber.

Serafim C. S. A., 78 anos, reformado, $4^{\circ}$ ano de escolaridade, natural de Campinho, residente em Reguengos de Monsaraz | Reguengos de Monsaraz | 3 de março de 20ı9 |

Io Motivo do sonho com um tesouro: APL I66 («Lenda do Monte da Antinha»). 
9

Havia pessoas que tinham muito ouro e dinheiro, libras em ouro e depoi, ali, nas Aldeias de Montoito, havia muita gente rica, daquela gente antiga que tinha muitas coisas dessas, muitas riquezas. E, depois, às vezes, andavam os ladrões a ver onde estava esse ouro pró roubari e elas muntas das vezes, isto o mundo é tão grande e há tanta coisa que a gente às vezes..., mas estas parece que eram verdades, que a minha mãe contava e lembra-se e odepois essas pessoas com medo nã lha roubassem metiam às vezes dentro dum azado ou duma panela e iam tarrar aquilo lá no sítio onde eles entendiam que ninguém mexia. E odepois havia pessoas, e odepois essas pessoas às vezes morriam e aquilo ficava lá.

E odepois havia pessoas que sonhavam com essas minas. Não tem ouvido dizeri sonhar com uma mina? É isso. E uma vez uma —isto contava a minha mãe, verdade, que ela soube que era verdade, que era a pessoa que lá foi fazer isso não sei se era afilhada da minha mãe, se era comadre, era pertencente, assim - era assim muito sabida e havia outra que era assim um bocadinho nencia e todas as noites, e havia no caminho das Aldeias para Montoito, havia uma árvi e tava lá uma laje ao pé daquela árvi, mas debaixo daquela laje 'tava terra', quando alevantavam a terra, a laje tava terra, mas se cavassem lá tava lá um azado com dinheiro e libras e ouro e tudo, lá naquele sítio. E odepois houve uma pessoa que era comadre da minha mãe e depôs sonhava com essa mina, mas não era assim munto esperta -Não sei se era a que foi tirari que era comadre da minha mãe, que ela contava se era a que sonhava, parece-me que era a que sonhava — disse assim:

— Ai, vezinha — ou comadre ou não sei quei — grande moenga, todas as nôtes, todas as nôtes, sonho com uma mina.

A outra como esperta [gargalhada]:

- Ainda tu dás credo nisso, comadre?! Ah, não deias credo. Tã tu se tivesses dinheiro ias o entarrari?!

Beim, uma lengalenga, e a outra dizendo:

- E tão como é que éi? Como é que não éi? Tão e como é que não éi? [Gargalhada] Ah, ainda tu dás credo nessas coisas?! Tã e desta maneira e tã daquela? Tã e a outra? Tã odepois assim? Tã odepois assado? — Tirando nabinhos da púquera.

E aquilo era tirado à meia-noite. Quando deram notícia, já a outra tinha ido tirar a mina com que aquela sonhou. [...]

Às vezes, tinham encantes. [...] Aquela não me lembra se tinha encante. Algumas tinham encantes, tinham que aturar o encante daquilo. Fazer lá certas coisas. Tinham um encante qualquer. Mas essa não me lembro. Parece que não tinha. Não sei se tinha se não. Já não me lembro.

Mas ela foi lá tirar a mina, tirou-a. Com um ganchinho, tirou-a, os nabinhos da púquera, e foi tirar a mina. A outra era parva... Sabendo tudo muito bem, foi lá tirar a mina. Ela começou a pulari, a vida dela e a outra... não sei se ela chegou a levar alguma sova do marido, se não. E a outra..., a vida dela pulou logo.

Delmira C., 93 anos, comerciante, $3^{\circ}$ ano de escolaridade, natural de Montoito, residente em Reguengos de Monsaraz | Reguengos de Monsaraz | 6 de dezembro de 20 II | 
$\mathrm{IO}^{\mathrm{II}}$

Diziam as pessoas antigas que em tendo uma mulher que tinha... parece-me que eram sete rapazes ou sete raparigas; se eram sete rapazes, um saía lobisomem e, se eram sete raparigas, uma saía bruxa, ou bruxa ou santa. [...]

Lobisomem têm aquele fadário. Sabe o que é fadário? Têm aquele fadário de fazer aquela coisa. Chama-se-lhe o fadário. E em chegando à meia-noite, não sei se têm dias marcados se não, isso não sei, e só fazem isto à meia-noite, numa encruzilhada duma estrada. Rabolam-se, não sei se dizem alguma coisa, se não, e depois ficam feitos num burro ou num cão, num animal, e abalam a correr aquele fadário, que o destino deles manda e, se chegam à porta duma pessoa, a pessoa tem medo, fecha a porta e eles às vezes atiram couces e assim.

E depois, em correndo aquele fadário que lá marca o destino deles, vão outra vez espojar-se lá nas coisas e ficam outra vez feito num homem.

E também ouvi dizer que se houvesse uma pessoa com coragem, quando ele despe a roupa e fica aleim, a roupa fica aleim, é à meia-noite, e a roupa fica na encruzilhada e ele vai correr o fadário e depois vem-se outra vez vestir além. E eu ouvi dizer nessa altura em que a gente ouvia dizer essas coisas, agora já não se fala nessas coisas.

Se houvesse uma pessoa com coragem, da família, uma pessoa qualquer, quando ele despe a roupa e vai correr o fadário e ouve. Parece-me que é que ouvia contar à minha mãe que uma vez uma pessoa que fez isso tinha o forno a arder e foi-lhe buscar a roupa e atirou com ela para dentro do, do forno, e a roupa ardeu e quebrou-lhe o fadário. Deixou de ser assim. [...]

Diziam essas coisas.

E olhe isso pode ser tudo conversas, mas eu acredito. Acredito porque antigamente havia muitas, muito, muito diferentes do que há agora.

Delmira C., 93 anos, comerciante, $3^{\circ}$ ano de escolaridade, natural de Montoito, residente em Reguengos de Monsaraz | Reguengos de Monsaraz | 6 de novembro de $201 \mathrm{I}$ |

II

«Medo do Roncão d'El Rei»

Há uma história muito engraçada, não sei se é verdade, se é mentira.

Reza a história que no Roncão d'El Rei, há muitos anos, então, naquele tempo, na herdade, havia uma manada de vacas, que à noite iam dormir à cabana, e havia alguém, havia uma voz que pedia favas fritas, e o vaqueiro ouvia aquela voz:

— Então, mas agora?!

E ele ameaçava:

- Se não me deres as favas fritas, solto-te as vacas todas.

II Motivo do encanto quebrado, com roubo e queima da roupa do lobisomem: APL I804 («O Lobisomem»).

Motivo da metamorfose em animal («num burro, num porco gordo»): APL I544 («Sete Irmãos») + Motivo do encanto quebrado, com roubo e queima da roupa do lobisomem: APL I544 («Sete Irmãos»). 
O homem, à primeira vez, não fez caso. Não fez caso e, quando foi ao fim dum bocado, as vacas estavam todas soltas — porque as vacas estão presas mesmo à manjedoura. E o homem:

- Então, mas tinha as vacas todas presas, já estão soltas?!

Ele lembrou-se da história, da voz que tinha ouvido:

- Ó tão, mas...

Ele indicava-lhe o local onde havia de pôr as favas e diz:

$-\mathrm{Ai}$...

Isso passou, esse dia. No outro dia, diz-lhe ele, a ouvir a voz:

- Não me deste favas fritas, mas, se hoje me deres as favas fritas, não precisas de prender as vacas, mete-as na cabana, que eu prendo as vacas.

E o homem:

- Ora, tão, olha, vou experimentar a ver se é verdade, se é mentira, já que apanhei a desilusão que me soltaram as vacas.

O homem esteve a fritar umas favas e pôs lá no local, onde o outro, a voz o mandou ir pôr as favas. Foi lá pôr as favas. Quando foi ao fim de um bocado, foi lá à cabana, estavam as vacas todas presas, reza a história. É verdade? É mentira? Não se sabe. Mas, no entanto, ficou a história das favas fritas.

Serafim C. S. A., 78 anos, reformado, $4^{\circ}$ ano de escolaridade, natural de Campinho, residente em Reguengos de Monsaraz | Reguengos de Monsaraz | 3 de março de 20ı9 |

I2a

«Lenda da Rocha do Vigio»

A Rocha do Vigio é no Degebe, lá na Defesa. É uma rocha pró lado do rio, assim coisa. Tem sete metros de altura. E caiu lá uma senhora lá pra baixo. Ficou nas silvas. Isto é já uma coisa muito antiga. É uma coisa muito antiga. E depois tiraram-na e não tinha nada. Aquilo há uma lenda ali, qualquer mistério na rocha. É na Defesa do Esporão.

Rosete F. R., 68 anos, reformada, $4^{\circ}$ ano de escolaridade, natural de Gafanhoeiras, residente em Reguengos de Monsaraz | Reguengos de Monsaraz | 24 de novembro de $201 \mathrm{O}$ |

$\mathrm{I} 2 \mathrm{~b}$

Há a rocha do Vigio e há uma outra rocha grande no Degebe, sã as duas no Degebe. E a outra que é aqui a rocha do Demo, daí garrearam dous touros e caíram, caíram lá para baixo. E essa houve uma moça que tava vivendo naquele monte dessa herdade. E foi lá um dia mais a gaiata [...] ver a rocha. E foi e viu a cobra e [...] e caiu. Mas estava lá um silvado, não morreu. Não morreu, até casou aqui com um moço das Perolivas. Não morreu e a gaiata correu ó monte a chamar a família e lá cortaram as silvas e tiraram-na e ficou um bocadito, muito arranhada delas, mas não morreu.

António R., 95 anos, analfabeto, reformado, natural de São Marcos do Campo, residente em São Marcos do Campo | São Marcos do Campo | 7 de dezembro de 20 II | 